\title{
Drainage Management Problems Evaluation: Case Study Baloza and EL-Farama Drains, North Sinai, Egypt
}

\author{
Mohamed Gabr \\ Civil Engineering Department, High Institute for Engineering and Technology, New Damietta, Egypt \\ Email:m_egabr@yahoo.com
}

How to cite this paper: Gabr, M. (2019) Drainage Management Problems Evaluation: Case Study Baloza and EL-Farama Drains, North Sinai, Egypt. Journal of Water Resource and Protection, 11, 675-689. https://doi.org/10.4236/jwarp.2019.116039

Received: July 18, 2018

Accepted: June 7, 2019

Published: June 10, 2019

Copyright $\odot 2019$ by author(s) and Scientific Research Publishing Inc. This work is licensed under the Creative Commons Attribution International License (CC BY 4.0).

http://creativecommons.org/licenses/by/4.0/

\section{cc (i) Open Access}

\begin{abstract}
Drainage management activities aim at maintaining the performance of drainage networks by assessing the major drainage management problems regarding sedimentation, bank erosion, vegetation, water quality, and biodiversity, to find appropriate solutions for channel improvement in order to increase agricultural productivity and maintain agricultural land and the surrounding environment. In this research, we evaluate the drainage management problems to the surface drains Baloza and EL-Farama in the cultivated Tina Plain region (21,000 hectares) North Sinai, Egypt to provide an accurate data to help decision-makers to know the status of maintenance of the watercourses and the need for improvement. For this, Intensive field investigations were carried out regarding a hydrographic survey of the actual drains cross-section using total station and aqua sounder devices, visual stream bank erosion survey, and vegetation survey. In addition, monthly water samples from the drainage water were treated and analyzed for physical and chemical, bacteriological related indices. The results showed, the studied drains suffer from sedimentation, vegetation infection, and bank erosion in some reaches and need remedy. Estimated sedimentation in EL-Farama Drain was 34369 $\mathrm{m}^{3} /$ year and in Baloza Drain $29153 \mathrm{~m}^{3} /$ year; bank slope failures upstream and downstream pump stations were recorded; the average weed infection ratio for both drains was $30 \%$. The results of water quality parameters showed acceptable concentrations for $\mathrm{BOD}, \mathrm{DO}, \mathrm{NO}_{3}$, and total coliform according to Egypt decree, 92/2013 for the protection of the Nile River and its waterways from pollution, except TDS (more than $10,000 \mathrm{mg} / \mathrm{L}$ ). The drainage water was classified as high saline and it was unacceptable for irrigation. Therefore, the author recommends to remove sedimentation and vegetation every 2 years by mechanical methods, applying gabions lining to prevent bank erosion, and treating drainage water using wetland system and utilizing the treated wastewater in fish farming.
\end{abstract}




\section{Keywords}

Drainage Management, Sedimentation, Vegetation, Water Quality, Surface Drains

\section{Introduction}

Drainage management activities are to keep drain systems functioning effectively and efficiently. Adequate drainage system, increases land productivity, and protects the environment. Drainage management major related problems were dealt with, sedimentation, vegetation, water quality, and biodiversity [1] [2] [3]. Sediment is a fertile environment for vegetation growth, especially in the case of freshwater. Brackish or muddy water during flood season has a severe effect on stream life and other water use (domestic supply, stock watering) [4] [5]. Three sources of sediments should be taken into consideration when we deal with sedimentation management: 1) Upland erosion caused by surface washed processes, concentrated flow and mass [6].2) Stream bed erosion where the forces of water are capable of removing bed material [7]. 3) Stream bank erosion where the water flowing over or through the stream bank and the discharge of concentrated runoff from other sources is enough to remove bank material [8]. Vegetation management activities increase channel hydraulic efficiency, and reduce channel bank erosion. Plant growth depends on many factors such as light, temperature, nutrient levels, both in the water column and in streambed sediments, and hydrologic regime. High levels of nutrients are increasing aquatic weed growth. Plant influence of the amount of sunlight fluctuated as it effects on the rates of photosynthesis and growth [9] [10] [11]. The velocity of flowing water effects on aquatic plants intensity and distribution, where more weeds are existing on slower moving water. Water quality problems are, polluted agriculture surface and subsurface drainage water, natural and constructed drainage networks which become sinks for several sediments and contaminants [12]. Water quality problems include high dissolved solids, low dissolved oxygen, high nutrient levels, high turbidity, high rates of trace elements, and biological contaminants [13]. Biodiversity problems relate to the polluted water in the new drains, cutoff, oxbow lakes of meanders, and wetlands agriculture development; it has a negative impact on the fish populations, plant communities, and many diverse animals. Therefore optimum drainage management mitigates the contamination and adversely effects on animal and aquatic life ecosystems [14]. Nowadays, due to the degradation of water resources and limitation, there is not much opportunity for increasing the total irrigated region; the common of the increase in output from irrigated agriculture will have to emanate from investments in developed irrigation and drainage practices in current agricultural areas [15] [16] [17]. Drainage is not only a tool to battle soil salinity and waterlogging but also it plays a main role in the preservation of investments in irrigation, promoting economic growth, and ensuring the sustainability of irrigated agriculture [18] [19] [20]. The Tina Plain region in the North Sinai, Egypt is a cultivated area of 
21000 hectares; the surface drains Baloza and EL-Farama bound the area from the south and north respectively. The North Sinai Sector for water resources and infrastructures, Ministry of Water Resources and Irrigation operates and manages the irrigation and drainage networks in the Tina Plain area since 1998. Therefore, the study of the drainage channel problems relating to sedimentation, vegetation, and water quality for the agriculture main drains Baloza and EL-Farama are needed to understand the processes taking place on-site to help decision-maker to apply sustainable agriculture drainage system. Therefore, in this research, we assess the major drainage channel problems relating to sedimentation, vegetation, and water quality for the agriculture main drains Baloza and EL-Farama, we assess the status of maintenance of the studied drains based on the measure of the drains actual cross-sections by hydrographic surveying, and survey vegetation infection. In addition, we assess the drainage water quality, we collect, treat, and analyze water samples from four locations in studying drains for all important water quality parameters total salinity (TDS, EC), temperature, $\mathrm{pH}$, organics (DO, BOD), nutrients $\left(\mathrm{NO}_{3}\right)$, major anions (Ca, $\left.\mathrm{Mg}, \mathrm{Na}, \mathrm{K}\right)$, major cations $\left(\mathrm{HCO}_{3}, \mathrm{CO}_{3}, \mathrm{Cl}, \mathrm{SO}_{4}\right)$, and pathogenicity (Total Coli.).

\section{Materials and Methods}

\subsection{Description of the Study Area}

The study area is located in the north Sinai, Egypt, where the North Sinai Development Project (NSDP) to reclaim and cultivate 168,000 hectares. The surface drains Baloza and EL-Farama are bounded the cultivated Tina Plain region (21,000 hectares) from south and north respectively (Figure 1). The Tina Plain region is a part of the Nile Delta, it is characterized by being flat topography with mean elevations of $1.0 \mathrm{~m}$ above mean sea level, and the predominate soil is clay [21]. The irrigation and drainage networks were operated and managed by the North Sinai Sector for Water Resources and Infrastructures (SWRI), Ministry of Water Resources and Irrigation (MWRI) since 1998. El-Sheikh Gaber Channel is the main irrigation channel in the NSDP, its discharge is $160 \mathrm{~m}^{3} / \mathrm{sec}$, and the irrigation water resources are fresh Nile water blended with agricultural drainage water in a ratio of 1:1 with a maximum salinity of $1000 \mathrm{ppm}$. The famous cultivated crops are wheat, sugar beet, bean, potatoes, tomatoes, besides vegetables and poplar trees. The climate of the region is semi-arid, characterized by two main seasons, a dry season from March to November and a rainy season in winter from December to February. The average annual precipitation ranges between $80-120 \mathrm{~mm}$ and annual temperature varies from $14.6^{\circ} \mathrm{C}$ the winter to $27^{\circ} \mathrm{C}$ in the summer. The average annual evaporation ranges from $100-120$ $\mathrm{mm}$. Baloza Drain serves an area of 23,100 hectares, the drain length is 17.480 $\mathrm{km}$, bed width varying from $2.0 \mathrm{~m}$ at the entrance to $10 \mathrm{~m}$ at the outlet with water depths $1.22 \mathrm{~m}$ to $1.97 \mathrm{~m}$ respectively and the inside slope is $3: 1$. At the drain outlet, a pump station exists at $3.500 \mathrm{~km}$, it pumps the drainage water into the Suez Canal through a carrier channel of $3.0 \mathrm{~km}$ length. EL-Farama Drain serves 


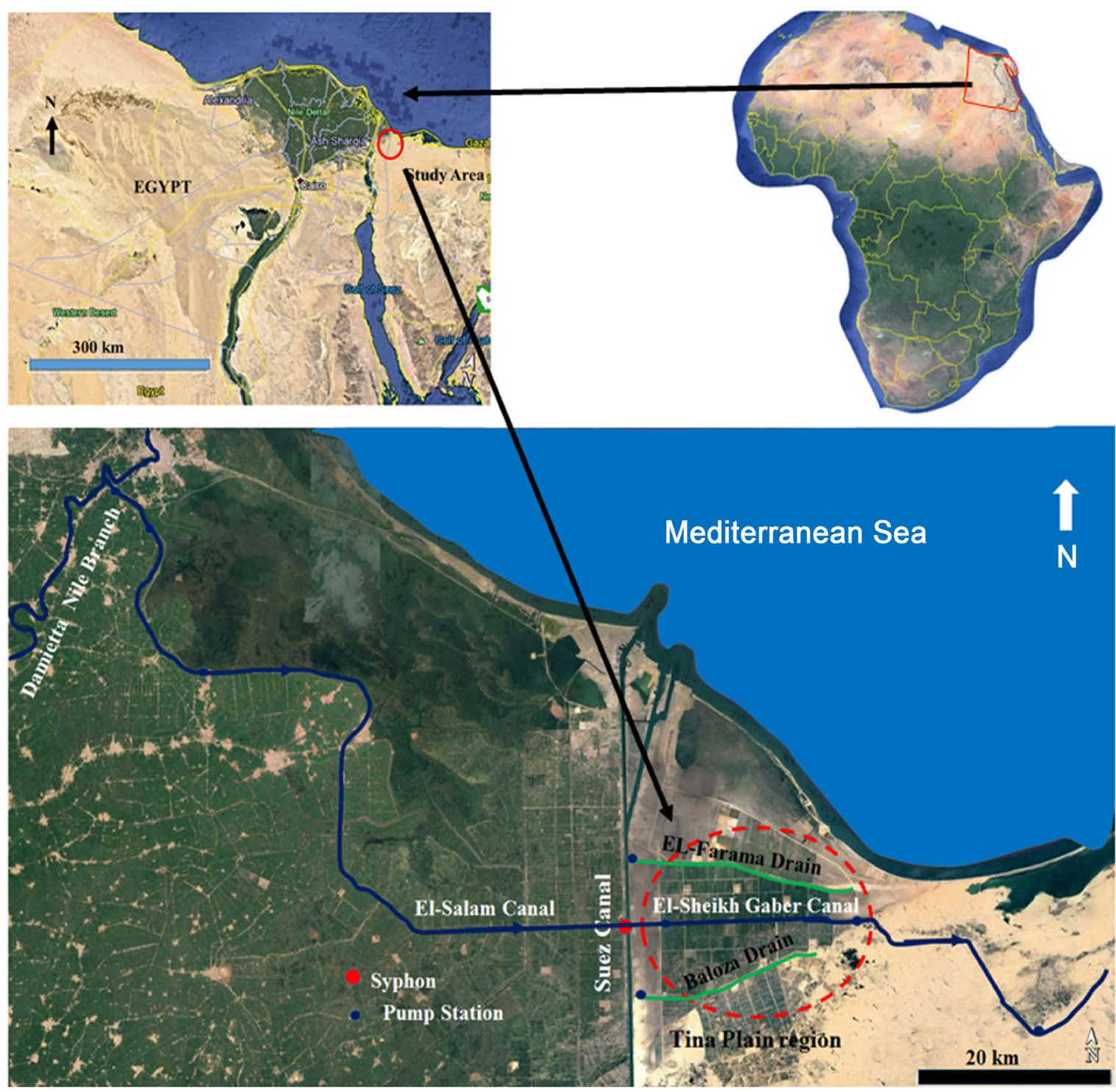

Figure 1. Location of Baloza and El-Faram drains in Tina Plain.

an area of 8400 hectares, the drain length is $17.480 \mathrm{~km}$, bed width varying from $2.0 \mathrm{~m}$ at the entrance to $10 \mathrm{~m}$ at the outlet with water depths $1.22 \mathrm{~m}$ to $1.97 \mathrm{~m}$ respectively, and the inside slope is $3: 1$. At the drain outlet, a pump station exists at $3.500 \mathrm{~km}$, to pump the drainage water into the Suez Channel through a carrier channel of $3.0 \mathrm{~km}$ length [22].

\subsection{Hydrographic Survey}

To examine the changes in the drain cross-section with respect to the designed cross-sections, groups of 18 cross-sections are distributed along the studied drains were selected according to, existing vegetation and existing hydraulic structures (Figure 2). The drains cross-sections were measured three times in one year, starting on August 2009, February 2010 and August 2010 using an echo sounder and total station survey devices. The actual cross-sections compare 


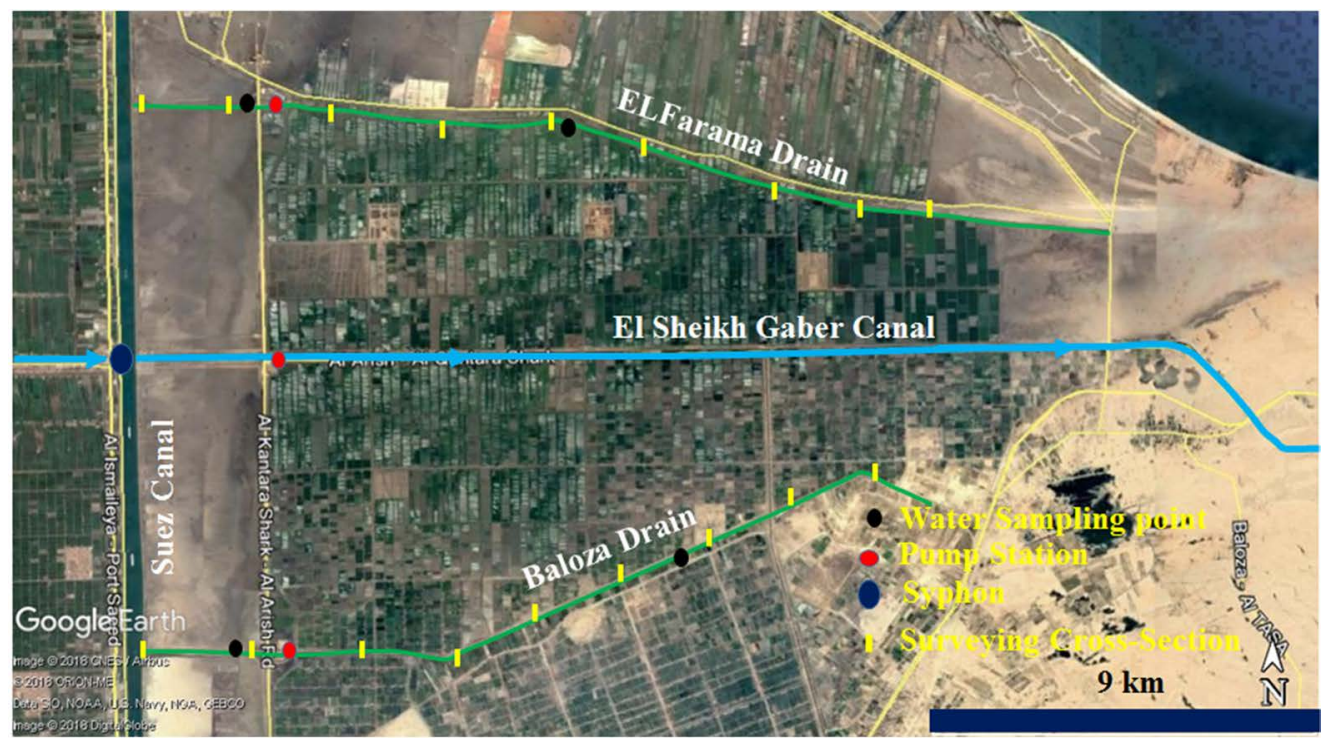

Figure 2. Hydrographic survey cross-sections locations and water sample locations.

with the designed ones, and the annual rate of sediments as a ratio of the designed cross-section area every 6 months is determined, additional details on the hydrographic survey are provided on [22].

\subsection{Monitoring the Aquatic Weeds}

A survey to measure the vegetation infection for the studied drains are carried out using a total station survey device; additional details on vegetation are provided in [22].

\subsection{Drainage Water Samples Collection and Analysis}

Water samples are collected every month from four monitoring locations, two locations in Baloza Drain, at N30 $57^{\prime} 29.81^{\prime \prime}, \mathrm{E} 32^{\circ} 20^{\prime} 56.95^{\prime \prime}$ (downstream pump station at $3.500 \mathrm{~km}$ from drain outlet), and at $2 \mathrm{~N} 30^{\circ} 59^{\prime} 16.16^{\prime \prime}, \mathrm{E} 32^{\circ} 28^{\prime} 7.94^{\prime \prime}$ (13.500 $\mathrm{km}$ from drain outlet). In addition, two locations in EL-Farama drain at $\mathrm{N} 31^{\circ} 4^{\prime} 21.91^{\prime \prime}, \mathrm{E} 32^{\circ} 20^{\prime} 46.91^{\prime \prime}$ (downstream pump station at $3.500 \mathrm{~km}$ from drain

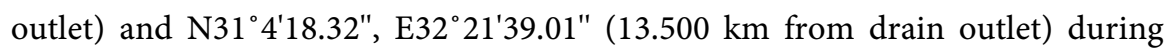
the period from 2010 to 2014 (Figure 2). When taking water samples principles in [23] were considered. Total salinity (Electrical Conductivity (EC), total dissolved solids (TDS)), temperature, $\mathrm{pH}$, were measured in situ. These parameters were measured using portable electrodes (Loveland). The rest of parameters, organics (DO, BOD), nutrients $\left(\mathrm{NO}_{3}\right)$, soluble ions (Ca, $\mathrm{Mg}, \mathrm{Na}, \mathrm{K}, \mathrm{HCO}_{3}, \mathrm{CO}_{3}, \mathrm{Cl}$, $\mathrm{SO}_{4}$ ), and pathogenicity (Total Coli.) were determined at the Center Laboratories for Environmental Quality Monitoring, National Water Research Center, Ministry of Water Resources and Irrigation, Cairo, Egypt.

Evaluation of the water quality data is carried out by statistical methods. The quality parameters like salinity (EC), (TDS), and toxicity due to chloride and sodium (sodium adsorption ratio (SAR) value is an indicator to predict permissible 
sodium levels in irrigation water to maintain soil structural stability) are determined to assess the suitability of drainage water to reuse in irrigation. To protect the non-fresh water resources, in case of discharging the drainage water into the sea, the measured drainage water parameters were compared with the Egyptian standards decree 92/2013, Executive Regulation of Law 48/1982 that protects non-fresh watercourses from pollution by the discharged effluents [24]. Additional details on the study of water quality for Baloza and EL-Farama drains are provided in [25].

Table 1, summarizes the calculated average annual cross-section deformation as a ratio of the designed cross-section for the period from August 2009 to February 2010 and from February 2010 to 2010 August for the studied drains, it shows sedimentation in all measured cross-sections. Figure 3 shows the cross-section deformation as a ratio of the designed cross-section area along EL-Farama drain path, the critical sedimentation reaches are from $0.250 \mathrm{~km}$ to $2.250 \mathrm{~km}$ and from $14.950 \mathrm{~km}$ to $19.50 \mathrm{~km}$ where, the reduction in the designed cross-section area ranges from $10.55 \%$ to $12.64 \%$ and $1.98 \%$ to $11.8 \%$ respectively. The total calculated annual sedimentation in EL-Farama Drain is 34,369 $\mathrm{m}^{3}$. Figure 4 shows the cross-section deformation as a ratio of the designed cross-section area along Baloza Drain path the critical sedimentation reaches are from $0.300 \mathrm{~km}$ to $3.300 \mathrm{~km}$ and from $11.300 \mathrm{~km}$ to $13.300 \mathrm{~km}$, the reduction in the designed cross-section area ranges from $9.64 \%$ to $7.51 \%$ and $4.785 \%$ to $7.74 \%$ respectively. The estimated total annual sedimentation is $29,153 \mathrm{~m}^{3}$. The increasing in sedimentation rates for the previous reaches are due to windblown during March month loaded with fine sands, coming from northern north west direction [21] [26]. The fallen sand inside watercourse reduces its cross section area, which so decreases storage capacity, constitutes a good environment for the growth of aquatic weeds, and effect on water quality, and reduces the hydraulic efficiency. Windbreakers of wooden trees (Casuarina and Equistifofia) of a matrix of one row can be used to reduce the fallen sand rates in the studied drains [21].

\section{Results and Discussions}

\subsection{Drains Cross-Section Area Deformation}

Table 1, summarizes the calculated average annual cross-section deformation as a ratio of the designed cross-section for the period from August 2009 to February 2010 and from February 2010 to 2010 August for the studied drains, it shows sedimentation in all measured cross-sections. Figure 3 shows the cross-section deformation as a ratio of the designed cross-section area along EL-Farama drain path, the critical sedimentation reaches are from $0.250 \mathrm{~km}$ to $2.250 \mathrm{~km}$ and from $14.950 \mathrm{~km}$ to $19.50 \mathrm{~km}$ where, the reduction in the designed cross-section area ranges from $10.55 \%$ to $12.64 \%$ and $1.98 \%$ to $11.8 \%$ respectively. The total calculated annual sedimentation in EL-Farama Drain is $34,369 \mathrm{~m}^{3}$. Figure 4 shows the cross-section deformation as a ratio of the designed cross-section area along 
Baloza Drain path the critical sedimentation reaches are from $0.300 \mathrm{~km}$ to $3.300 \mathrm{~km}$ and from $11.300 \mathrm{~km}$ to $13.300 \mathrm{~km}$, the reduction in the designed cross-section area ranges from $9.64 \%$ to $7.51 \%$ and $4.785 \%$ to $7.74 \%$ respectively. The estimated total annual sedimentation is $29,153 \mathrm{~m}^{3}$. The increasing in sedimentation rates for the previous reaches are due to windblown during March month loaded with fine sands, coming from northern north west direction [21] [26]. The fallen sand inside watercourse reduces its cross section area, which so decreases storage capacity, constitutes a good environment for the growth of aquatic weeds, and effect on water quality, and reduces the hydraulic efficiency. Windbreakers of wooden trees (Casuarina and Equistifofia) of a matrix of one row can be used to reduce the fallen sand rates in the studied drains [21].

Table 1. Calculated average annual cross-section deformation as a ratio of the designed cross-section area.

\begin{tabular}{|c|c|c|c|c|c|}
\hline \multirow{2}{*}{$\begin{array}{l}\text { Drain } \\
\text { name }\end{array}$} & \multirow{2}{*}{$\begin{array}{l}\text { Cross-Section } \\
\text { No. }\end{array}$} & \multirow{2}{*}{$\begin{array}{l}\text { Location } \\
(\mathrm{km})\end{array}$} & \multicolumn{3}{|c|}{$\begin{array}{l}\text { Cross-section deformation ratio } \\
\text { ( } \% \text { of the designed cross-section area) }\end{array}$} \\
\hline & & & $\begin{array}{c}\text { During period } \\
\text { from August } 2009 \\
\text { to February } 2010\end{array}$ & $\begin{array}{l}\text { During period from } \\
\text { February } 2010 \text { to } \\
\text { August } 2010\end{array}$ & $\begin{array}{l}\text { Yearly } \\
\text { average }\end{array}$ \\
\hline \multirow{9}{*}{ EL-Farama } & 1 & 0.250 & 1.87 & 1.93 & 1.90 \\
\hline & 2 & 2.250 & 13.00 & 9.55 & 11.28 \\
\hline & 3 & 5.000 & 8.00 & 7.65 & 7.83 \\
\hline & 4 & 7.500 & 1.00 & 4.81 & 2.91 \\
\hline & 5 & 10.000 & 5.00 & 5.11 & 5.06 \\
\hline & 6 & 12.400 & 3.68 & 4.23 & 3.96 \\
\hline & 7 & 14.950 & 11.96 & 9.13 & 10.55 \\
\hline & 8 & 17.500 & 11.00 & 10.15 & 10.58 \\
\hline & 9 & 19.500 & 14.15 & 11.12 & 12.64 \\
\hline \multirow{9}{*}{ Baloza } & 1 & 0.300 & 2.00 & 7.56 & 4.78 \\
\hline & 2 & 3.300 & 8.04 & 7.44 & 7.74 \\
\hline & 3 & 5.300 & 2.99 & 4.17 & 3.58 \\
\hline & 4 & 7.300 & 3.73 & 3.77 & 3.75 \\
\hline & 5 & 9.300 & 2.63 & 3.66 & 3.15 \\
\hline & 6 & 11.300 & 10.16 & 9.11 & 9.64 \\
\hline & 7 & 13.300 & 7.96 & 7.05 & 7.51 \\
\hline & 8 & 15.300 & 4.42 & 4.58 & 4.50 \\
\hline & 9 & 17.300 & 6.75 & 9.41 & 8.08 \\
\hline
\end{tabular}

${ }^{1}$ Positive values means sedimentation. 


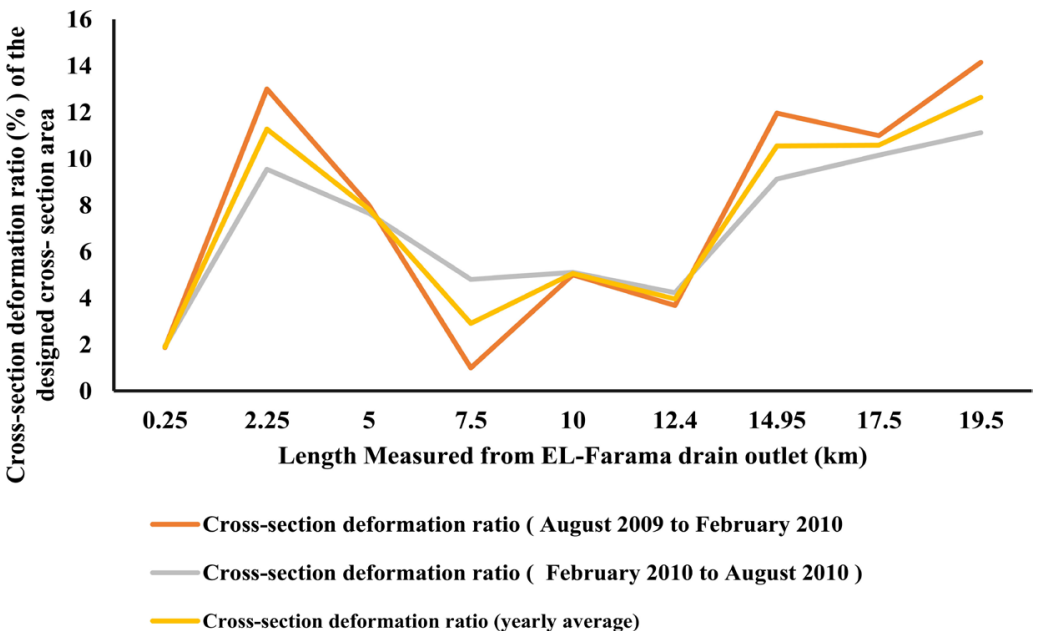

Figure 3. EL-Farama Drain, calculated average annual cross-section deformation (sedimentation) as a ratio of the designed cross-section area.

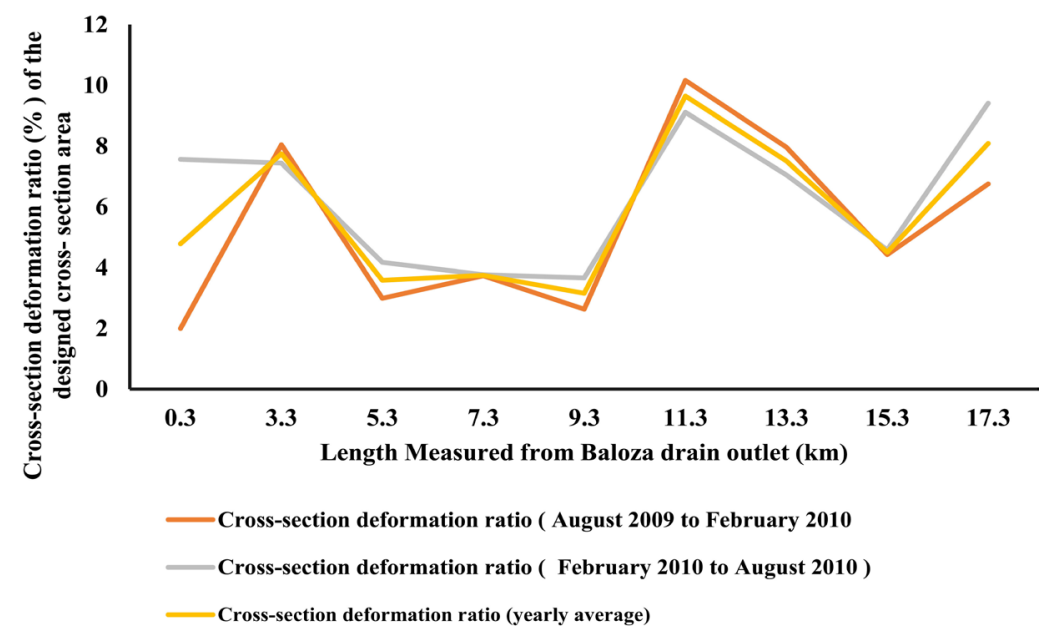

Figure 4. Baloza Drain, calculated average annual cross-section deformation (sedimentation) as a ratio of the designed cross-section area.

\subsection{Vegetation Infection}

Table 2 summarizes weeds types and its infection percentage in the studied drains. Looking at Table 2, the weed infection ratio for Baloza Drain at the reach from $0.00 \mathrm{~km}$ to $3.30 \mathrm{~km}$ is $30 \%$, the reach from $0.00 \mathrm{~km}$ to $3.30 \mathrm{~km}$ is $40 \%$, the reach from $5.50 \mathrm{~km}$ to $7.0 \mathrm{~km}$ is $30 \%$, and the reach from $7.00 \mathrm{~km}$ to $9.30 \mathrm{~km}$ the weed infection ratio is 20\%. The Phragmites australis, Cyperus articulates and Ceratophyllum demersum were the exiting vegetation. For EL-Farama Drain the reach from $0.00 \mathrm{~km}$ to $3.00 \mathrm{~km}$ the weed infection ratio is $30 \%$, Phragmites australis, Cyperus articulates, and Ceratophyllum demersum were the exiting vegetation. Vegetation is the extension of plant diversity of the Damietta Branch, River Nile, Egypt [27].

\subsection{Bank Erosion}

Bank slope failures upstream and downstream pumps were recorded up stream 
Table 2. Weeds types and its infection percentage the studied drains.

\begin{tabular}{cccc}
\hline Drain name & Cross-Section No. & $\begin{array}{c}\text { Weed infection } \\
\text { ratio (\%) }\end{array}$ & Types of exiting vegetation \\
\hline Baloza Drain & $0.00 \mathrm{~km}-3.30 \mathrm{~km}$ & 30 & $\begin{array}{c}\text { Phragmites australis, Cyperus articulates } \\
\text { and Ceratophyllum demersum }\end{array}$ \\
& $3.30 \mathrm{~km}-5.50 \mathrm{~km}$ & 40 & \\
& $5.50 \mathrm{~km}-7.00 \mathrm{~km}$ & 30 & \\
& $7.00 \mathrm{~km}-9.30 \mathrm{~km}$ & 20 & \\
EL-Farama Drain & $0.00 \mathrm{~km}-3.00 \mathrm{~km}$ & 30 & $\begin{array}{c}\text { Phragmites australis, Cyperus articulates } \\
\text { and Ceratophyllum demersum }\end{array}$ \\
\hline
\end{tabular}

and down steam pump stations. The soil analysis for drains bed and banks [22] showed that the soil classification for El-Faram Drain soil classification at the bed at $0.250 \mathrm{~km}$ was silty clay, at right bank $7.500 \mathrm{~km}$ was silty sand, and at right bank, $7.500 \mathrm{~km}$ was silty clay. For Baloza Drain soil classification is sandy soil. Lining of the drains inside slopes with riprap or gabions was recommended to prevent bank erosion [28].

\subsection{Methodology for Channel Maintenance Method}

To identify the channel priority to be maintained the following steps are essential:

\section{Step 1: Define the related geometry and features of the channel}

Based on the national database for the Egyptian Ministry of Water Resources and Irrigation (MWRI) the geometry of the cross-section, the bed slope of the reach, and the type of vegetation, which defines the roughness coefficient, are determined for all the main watercourses in Egypt. The national database is used to obtain this information, although it is acknowledged that local information, when available, may provide more reliable and accurate inputs.

Step 2: Describe maintenance scenarios (Comprising sediment and vegetation management)

Maintenance scenarios depend on characteristics of the watercourse, and the results of sedimentation and vegetation surveying.

\section{Step 3: Compute the impact of maintenance}

The variation in the conveyance capacity of the main channel (expressed as a percentage) is utilized to compute the impacts of maintenance. This parameter estimates for all watercourses in order to deliver a simple and reliable measure of the impacts of maintenance works.

\section{Step 4: Detecting the ideal management option}

The choice of the ideal maintenance option is based on the chance of the attributes in a watercourse length of the highest impacts on conveyance management and highest benefits associated to the watercourse. Information provided by the MWRI is used to estimate the costs of vegetation maintenance works, defined as pounds per meter. The ratio between benefits and costs is utilized to choose the preferred maintenance option on a particular channel, which 
is the one with the largest ratio in the case of dredging, it is not possible to state the cost of the works at the national level due to the large differences depending on the features of the site. The costing of this type of works also requires to take into consideration the disposal of material off-site, which could have large variations. We suggest a maintenance program for the studied drains to remove the sedimentation and vegetation every 2 years from the most exposed reaches by utilizing a hydraulic excavator with a long boom (Table 3 ).

\subsection{Drainage Water Quality}

Analytical results for the chemical, physical, and bacteriological water quality parameters including statistical analysis, such as maximum, minimum, mean and standard deviation are summarized in Table 4 \& Table 5 for Baloza and

Table 3. Suggested maintenance program for the studied surfaces drains

\begin{tabular}{|c|c|c|c|c|c|c|}
\hline \multirow{3}{*}{ Watercourse } & \multicolumn{6}{|c|}{ Maintenance Type } \\
\hline & \multicolumn{3}{|c|}{ Vegetation Removing } & \multicolumn{3}{|c|}{ Sedimentation Removing } \\
\hline & Procedure & Machine & Annual rate & Procedure & Machine & Annual rate \\
\hline Baloza Drain & Mechanical & $\begin{array}{l}\text { Hydraulic Excavator with long } \\
\text { boom and vegetation cutting bucket }\end{array}$ & $1 / 2$ (Every 2 years) & Mechanical & $\begin{array}{l}\text { Hydraulic Excavator with long boom } \\
\text { and sedimentation dredging bucket }\end{array}$ & $\begin{array}{l}1 / 2 \text { (Every } \\
2 \text { years) }\end{array}$ \\
\hline
\end{tabular}

Table 4. Summary statistics water quality parameters in Baloza drain for the two monitoring sites from 2010 to 2014 compared to limit by Egypt decree [24].

\begin{tabular}{ccccccc}
\hline Indicator/measure & Unit & Max. & Min. & $\begin{array}{c}\text { Standard } \\
\text { Deviation }\end{array}$ & Mean & $\begin{array}{c}\text { Limit by Egypt } \\
\text { decree [24] }\end{array}$ \\
\hline $\mathrm{PH}$ & - & 8 & 8 & 0.1 & 8 & $6-9$ \\
$\mathrm{EC}$ & $\mathrm{ds} / \mathrm{m}$ & 29.1 & 12 & 6.8 & 19 & 7.8 \\
$\mathrm{TDS}$ & $\mathrm{mg} / \mathrm{L}$ & 18633 & 7680 & 4343.1 & 12464 & $<5000$ \\
Temperature & ${ }^{\circ} \mathrm{C}$ & 23.1 & 15 & 2.7 & 20 & $>3$ \\
$\mathrm{SAR}$ & $\mathrm{mg} / \mathrm{L}$ & 88.6 & 20 & 20.4 & 43 & - \\
$\mathrm{Ca}$ & $\mathrm{mg} / \mathrm{L}$ & 53.2 & 9 & 12.1 & 22 & - \\
$\mathrm{Mg}$ & $\mathrm{mg} / \mathrm{L}$ & 37 & 12 & 7.0 & 23 & - \\
$\mathrm{Na}$ & $\mathrm{mg} / \mathrm{L}$ & 333.9 & 85 & 71.4 & 164 & - \\
$\mathrm{K}$ & $\mathrm{mg} / \mathrm{L}$ & 3.1 & 1 & 0.7 & 2 & - \\
$\mathrm{CO}_{3}$ & $\mathrm{mg} / \mathrm{L}$ & 0 & 0 & 0 & 0 & - \\
$\mathrm{HCO}$ & $\mathrm{mg} / \mathrm{L}$ & 6.9 & 2 & 1.4 & 4 & - \\
$\mathrm{Cl}_{3}$ & $\mathrm{mg} / \mathrm{L}$ & 322.6 & 82 & 71.4 & 174 & - \\
$\mathrm{SO}_{4}$ & $\mathrm{mg} / \mathrm{L}$ & 52 & 11 & 11.7 & 35 & - \\
$\mathrm{DO}$ & $\mathrm{mg} / \mathrm{L}$ & 7.8 & 4 & 1.0 & 6 & $>5$ \\
$\mathrm{BOD}$ & $\mathrm{mg} / \mathrm{L}$ & 13.8 & 6 & 2.1 & 11 & $<60$ \\
$\mathrm{NO}_{3}$ & $\mathrm{mg} / \mathrm{L}$ & 5.7 & 3 & 1.0 & 4 & - \\
Total Coli. & $\mathrm{MPN} / 100 \mathrm{ml}$ & 3957 & 233 & 1218.7 & 1524 & $<5000$ \\
\hline & & & & & & -
\end{tabular}


Table 5. Summary statistics water quality parameters in EL-Farama drain for the two monitoring sites from 2010 to 2014 compared with the limit by Egypt decree [24].

\begin{tabular}{ccccccc}
\hline Indicator/measure & Unit & Max. & Min. & $\begin{array}{c}\text { Standard } \\
\text { Deviation }\end{array}$ & Mean & $\begin{array}{c}\text { Limit by Egypt } \\
\text { decree [24] }\end{array}$ \\
\hline PH & - & 8.1 & 8 & 0.1 & 8 & $6-9$ \\
EC & $\mathrm{ds} / \mathrm{m}$ & 17.3 & 9 & 2.4 & 12 & 7.8 \\
TDS & $\mathrm{mg} / \mathrm{L}$ & 11053.0 & 5955 & 1534.1 & 7473 & $<5000$ \\
Temperature & ${ }^{\circ} \mathrm{C}$ & 22.8 & 15 & 2.5 & 20 & $>3$ \\
$\mathrm{SAR}$ & $\mathrm{mg} / \mathrm{L}$ & 48.5 & 15 & 11.0 & 30 & - \\
$\mathrm{Ca}$ & $\mathrm{mg} / \mathrm{L}$ & 22.1 & 6 & 5.9 & 15 & - \\
$\mathrm{Mg}$ & $\mathrm{mg} / \mathrm{L}$ & 20.1 & 11 & 2.9 & 16 & - \\
$\mathrm{Na}$ & $\mathrm{mg} / \mathrm{L}$ & 98.6 & 63 & 11.8 & 80 & - \\
$\mathrm{K}$ & $\mathrm{mg} / \mathrm{L}$ & 2.2 & 1 & 2.9 & 3 & - \\
$\mathrm{CO}_{3}$ & $\mathrm{mg} / \mathrm{L}$ & 0.0 & 0 & 0.0 & 0 & - \\
$\mathrm{HCO}{ }_{3}$ & $\mathrm{mg} / \mathrm{L}$ & 6.7 & 3 & 1.2 & 4 & - \\
$\mathrm{Cl}$ & $\mathrm{mg} / \mathrm{L}$ & 157.7 & 68 & 30.4 & 94 & - \\
$\mathrm{SO}_{4}$ & $\mathrm{mg} / \mathrm{L}$ & 32.0 & 8 & 8.3 & 23 & - \\
$\mathrm{DO}$ & $\mathrm{mg} / \mathrm{L}$ & 8.7 & 6 & 0.7 & 7 & $>5$ \\
$\mathrm{BOD}$ & $\mathrm{mg} / \mathrm{L}$ & 18.0 & 9 & 2.6 & 13 & $<60$ \\
$\mathrm{NO}_{3}$ & $\mathrm{mg} / \mathrm{L}$ & 5.6 & 3 & 0.9 & 4 & - \\
Total Coli. & $\mathrm{MPN} / 100 \mathrm{ml}$ & 4986.0 & 174 & 1299.0 & 1732 & $<5000$ \\
\hline
\end{tabular}

Table 6. Water classification by salinity.

\begin{tabular}{ccc}
\hline Water quality grade & EC $(\mathrm{dS} / \mathrm{m})$ & $(\mathrm{TDS} \mathrm{mg} / \mathrm{L})$ \\
\hline Non-saline water & $<0.7$ & $<500$ \\
Saline water & $0.7-42$ & $500-3000$ \\
Slightly saline & $0.7-3.0$ & $5000-2000$ \\
Medium saline & $3-6$ & $2000-4000$ \\
Highly saline & $>6.0$ & $>4000$ \\
Very saline & $>14$ & $>9000$ \\
Brine & $>42$ & $>30,000$ \\
\hline
\end{tabular}

FAO, 2007 [29].

EL-Farama Drains respectively. For Baloza Drain water temperature ranges from $15^{\circ} \mathrm{C}$ to $23.1^{\circ} \mathrm{C}$ with an average of $\left(20^{\circ} \mathrm{C} \pm 2.7^{\circ} \mathrm{C}\right)$, $\mathrm{pH}$ is $(8 \pm 0.1)$ indicating alkaline water. TDS ranges from $7680 \mathrm{mg} / \mathrm{L}$ to $18,633 \mathrm{mg} / \mathrm{L}$ with an average $(12,464 \pm 4343.1) \mathrm{mg} / \mathrm{L}$, TDS is unacceptable according to Egyptian local low Egyptian decree $92 / 2013$. The drainage water quality classifies as a high saline according to [29] (Table 6). EC ranges from 12 to $29.1 \mathrm{dS} / \mathrm{m}$ with an average (19 $\pm 6.8) \mathrm{mg} / \mathrm{L}$ indicating high saline water. SAR is calculated using the formula presented in [29], it ranges from 20 to $88.6 \mathrm{mg} / \mathrm{L}$ with an average $(43 \pm 20.4)$ $\mathrm{mg} / \mathrm{L}$ indicates slight reduction potential infiltration problem. DO ranges from 4 to $7.8 \mathrm{mg} / \mathrm{L}$ with an average $(6 \pm 1) \mathrm{mg} / \mathrm{L}$ indicates good dissolved oxygen, BOD 
ranges from 6 to $13.8 \mathrm{mg} / \mathrm{L}$ with an average $(11 \pm 2.1) \mathrm{mg} / \mathrm{L}$ indicates acceptable $\mathrm{BOD}<60 \mathrm{mg} / \mathrm{L}$ according to [24]. $\mathrm{NO}_{3}$ ranges from 3 to $5.7 \mathrm{mg} / \mathrm{L}$ with an average $(4 \pm 1) \mathrm{mg} / \mathrm{L}$. In addition, the Total Coli. ranges from 174 to 4986 in MPN/100 $\mathrm{ml}$ with an average of $(1524 \pm 1218.7)$ in MPN/100 ml acceptable according to [24]. The abundance of cations in the drainage water is in the following order: $\mathrm{Na}^{+}>\mathrm{Mg}^{2+}>\mathrm{Ca}^{2+}>\mathrm{K}^{+}$. The concentrations of cations are $(80 \pm 11.8)$ $\mathrm{mg} / \mathrm{L},(16 \pm 2.9) \mathrm{mg} / \mathrm{L},(15 \pm 5.9) \mathrm{mg} / \mathrm{L}$, and $(3 \pm 2.9) \mathrm{mg} / \mathrm{L} \mathrm{mg} / \mathrm{L}$ for $\mathrm{Na}^{+}, \mathrm{Mg}^{2+}$, $\mathrm{Ca}^{2+}$, and $\mathrm{K}^{+}$respectively. Chloride is the dominant anion, followed by sulfate and bicarbonate. The average concentrations of the anions $\mathrm{Cl}, \mathrm{SO}_{4}$, and $\mathrm{HCO}_{3}$ are $(174 \pm 71.4) \mathrm{mg} / \mathrm{L},(35 \pm 11.7) \mathrm{mg} / \mathrm{L}$, and $(4 \pm 1.4) \mathrm{mg} / \mathrm{L}$ respectively. For EL-Farama Drain temperature ranges from $\left(14.9^{\circ} \mathrm{C}\right.$ to $\left.22.9^{\circ} \mathrm{C}\right)$ with an average $\left(19.9^{\circ} \mathrm{C} \pm 2.6^{\circ} \mathrm{C}\right), \mathrm{pH}$ ranges from 7.8 to 7.9 with an average $(7.9 \pm 0.1)$ indicates alkaline water. TDS ranges from $7680 \mathrm{mg} / \mathrm{L}$ to $9612 \mathrm{mg} / \mathrm{L}$ with an average $(8774$ $\pm 681.7) \mathrm{mg} / \mathrm{L}$, TDS is unacceptable according to Egyptian local decree 92/2013 [24] and the drainage water quality classify as a high saline (Table 6) [29]. EC ranges from 12 to $15 \mathrm{dS} / \mathrm{m}$ with an average (13.7 \pm 1.1$)$ indicate high saline water. SAR ranges from 20.2 to $54.3 \mathrm{mg} / \mathrm{L}$ with an average $(33 \pm 12.1) \mathrm{mg} / \mathrm{L}$ indicates slight reduction potential infiltration problem. DO ranges from 4.5 to 6.7 $\mathrm{mg} / \mathrm{L}$ with an average $(5.5 \pm 0.9)$ indicates good dissolved oxygen, BOD ranges from 10 to $13.2 \mathrm{mg} / \mathrm{L}$ with an average $(11.7 \pm 1.1) \mathrm{mg} / \mathrm{L}$ indicates acceptable $\mathrm{BOD}<60 \mathrm{mg} / \mathrm{L} . \mathrm{NO}_{3}$ ranges from 2.8 to $5.4 \mathrm{mg} / \mathrm{L}$ with an average $(3.8 \pm 0.9)$ $\mathrm{mg} / \mathrm{L}$ and the Total Coli. ranges from 275 to 3957 in MPN/100ml with an average of $(2330.4 \pm 1206)$ in MPN/100 ml, it is acceptable according to [24]. The abundance of cations in the drainage water is in the following order: $\mathrm{Na}^{+}>$ $\mathrm{Mg}^{2+}>\mathrm{Ca}^{2+}>\mathrm{K}^{+}$. The average concentrations of cations averages are (107.2 \pm $21.5) \mathrm{mg} / \mathrm{L},(17.7 \pm 4.3) \mathrm{mg} / \mathrm{L},(16.3 \pm 6.5) \mathrm{mg} / \mathrm{L}$, and $(1.5 \pm 0.4) \mathrm{mg} / \mathrm{L} \mathrm{mg} / \mathrm{L}$ for $\mathrm{Na}+, \mathrm{Mg}^{2+}, \mathrm{Ca}^{2+}$, and $\mathrm{K}^{+}$respectively. Chloride is the dominant anion, followed by sulfate and bicarbonate. The average concentrations of the anions $\mathrm{Cl}, \mathrm{SO}_{4}$, and $\mathrm{HCO}_{3}$ are $(114.5 \pm 24.8) \mathrm{mg} / \mathrm{L},(28.7 \pm 11.1) \mathrm{mg} / \mathrm{L}$, and $(3.3 \pm 0.7) \mathrm{mg} / \mathrm{L}$ respectively.

\section{Suitability of drainage water for irrigation}

The general criteria for assessing the drainage water quality to be used in irrigation are based on the total concentration of dissolved salts (TDS); relative proportion of sodium to other principal cations, the relative proportion of bicarbonate to calcium and magnesium, and elements that may be toxic (sulfates concentration and chloride concentration) (Table 7) reflect high saline water. According to [29] [30] Baloza drainage water is unacceptable for irrigation.

\section{Conclusions and Recommendations}

Drainage management activities are to keep drain systems functioning effectively and efficiently. Field investigation of the drainage management problems is an important tool to provide accurate data to help decision-makers to know the status of maintenance of the watercourses and the need for improvement. In the present study, major drainage management problems regarding sedimentation, 
Table 7. Water quality for irrigation.

\begin{tabular}{ccccccc}
\hline \multirow{2}{*}{$\begin{array}{c}\text { Classes } \\
\text { of Water }\end{array}$} & \multicolumn{5}{c}{ Parameters } & \\
\cline { 2 - 6 } & $\begin{array}{c}\mathrm{TDS} / \mathrm{L} \\
\mathrm{mg}\end{array}$ & $\begin{array}{c}\mathrm{SO}_{4} \\
\mathrm{mg} / \mathrm{L}\end{array}$ & $\begin{array}{c}\mathrm{Cl} \\
\mathrm{mg} / \mathrm{L}\end{array}$ & $\begin{array}{c}\mathrm{EC} \\
\mathrm{dS} / \mathrm{m}\end{array}$ & $\begin{array}{c}\text { SAR } \\
\%\end{array}$ & \\
\hline I & $0-700$ & $0-192$ & $0-142$ & $0-0.75$ & $<1$ & Excellent to good for irrigation \\
II & $700-2000$ & $192-480$ & $142-355$ & $0.75-2.25$ & $5-11$ & Good to harmful suitable soil \\
III & $>2000$ & $>480$ & $>355$ & $>2.25$ & $>23$ & Unfit for soil \\
\hline
\end{tabular}

Kumar, et al. 2007 [30].

bank erosion, vegetation, and water quality were investigated for the surface drains Baloza and EL-Farama in the cultivated Tina Plain region (21,000 hectares) North Sinai, Egypt. The summarized conclusions are as follows. The studied drains suffer from sedimentation, vegetation infection, and bank erosion in some reaches and need remedy. The choice of the ideal maintenance option is based on the highest impacts on conveyance management and highest benefits associated to the watercourse. High measured annual sedimentation volume for EL-Farama drain is $34,369 \mathrm{~m}^{3} /$ year. High measured annual sedimentation volume for Baloza is 29,153 $\mathrm{m}^{3} /$ year. Measured average weeds infection ratio is $30 \%$. Bank slope failures upstream and downstream pump stations were recorded. The average weed infection ratio for both drains is $30 \%$. Drainage water quality classifies as high saline water, $\mathrm{BOD}, \mathrm{DO}, \mathrm{NO}_{3}$, and total coliform at the permitted limits of the Egypt decree (92/2013), except for TDS (more than 10,000 mg/L). Therefore, Baloza and El-Farama drainage water is unacceptable for reusing in irrigation. Thus, for sustainable drainage management we suggest a maintenance program to remove sedimentation and vegetation every 2 years from the most exposed reaches utilizing a hydraulic excavator with a long boom, applying gabions lining to prevent bank erosion, and treating drainage water using constructed wetland systems.

\section{Acknowledgements}

I am thankful for the logistical and technical support provided by the Sector of Water Resources, Irrigation and Infrastructures, North Sinai, Ministry of Water Resources and Irrigation (MWRI), Egypt, and the Egyptian Channel Maintenance Research Institute (CMRI), National, (MWRI). During the research period, the author was a senior engineer in the Studies and Design Directorate, Sector of Water Resources, Irrigation and Infrastructures, North Sinai, MWRI, supervising the study of assessing of the irrigation and drainage network maintenance at the North Sinai Project, North Sinai.

\section{Conflicts of Interest}

The author declares no conflict of interest.

\section{References}

[1] New Zealand Water Environment Research Foundation (NZWERF) (2005) Sus- 
tainable Drainage Management-Field Guide. Wellington.

[2] Walter, O. and Hervé, P. (2005) Water Resources and Environment Technical Note E.1, Irrigation and Drainage Development. International Bank for Reconstruction and Development, the World Bank, Washington DC.

[3] Essex County Council Environment (ECC) (2016) Sustainable Drainage Systems Design Guide. Sustainability \& Highways. http://www.essex.gov.uk/flooding

[4] Arcement, G.J. and Schneider, V.R. (1989) Guide for Selecting Manning's Roughness Coefficients for Natural Channels and Flood Plains. United States Geological Survey Water Supply, Paper 2339.

[5] Peter, C. and Scott, M. (1984) Stream Bank Erosion Protection and Channel Scour Manipulation Using Rock fill Dikes and Gabion. Water Resources Research Institute Oregon State University, Corvallis, WRRI-98, PAP-734.

[6] King County Department (KCD) of Public Works Surface Water Management Division (1993) Guide Lines for Bank Stabilization Projects: In Riverine Environments of King County. Seattle.

[7] Steve, J. (2002) Stream Channel and Floodplain Erosion. Water and Rivers Commission, Hyatt Centre, East Perth, Western Australia, Report No. RR18.

[8] Iowa Department of Natural Resources (IDNR) in Cooperation with the Natural Resources Conservation Service (2006) How to Control Streambank Erosion Iowa Department of Natural Resources. U.S. Department of Agriculture, Washington DC.

[9] Siwan, L. and Phil, P. (1999) Riparian Land Management Technical Guidelines. Volume One: Principles of Sound Management. Land and Water Resources Research and Development Corporation (LWRRDC), Canberra.

[10] U.S. Army Corps of Engineers (USACE) (2007) White Paper: Treatment of Vegetation within Local Flood-Damage-Reduction Systems. Washington DC.

[11] U.S. Army Corps of Engineers (USACE) (2014) Guidelines for Landscape Planting and Vegetation Management at Levees, Floodwalls, Embankment Dams and Appurtenant Structures. Engineering Technical Letter (ETL) 1110-2-583, Washington DC.

[12] Kostas, V. and Dimitra, V. (2012) Water Quality Monitoring and Assessment. InTech, Rijeka.

[13] Department of Environment and Heritage Protection (DEHP), Department of Science, Information Technology and Innovation, Environmental Protection, Water Policy (2017) Monitoring and Sampling Manual Sampling Design and Preparation Version. Consultation DRAFT, Queensland Government.

[14] Neil, A., Michael, V., Lloyd, F., Kevin, W. and Jessica, D. (2013) Alternative Technology for Storm Water Management the South African Guidelines for Sustainable Drainage Systems. Report to the Water Research Commission by University of Cape Town, Cape Town, WRC Report No. TT 558/13.

[15] Muema, F.M., Home, P.G. and Raude, J.M. (2018) Application of Benchmarking and Principal Component Analysis in Measuring Performance of Public Irrigation Schemes in Kenya. Agriculture, 8, 162. https://doi.org/10.3390/agriculture8100162

[16] Schultz, B., Thatte, C.D. and Labhsetwar, V.K. (2015) Irrigation and Drainage: Main Contributors to Global Food Production. Irrigation and Drainage, 54, 263-278. https://doi.org/10.1002/ird.170

[17] Osman, I.E. (2015) Impact of Improved Operation and Maintenance on Cohesive Sediment Transport in Gezira Scheme, Sudan. Wageningen University, UNESCO-IHE 
Institute for Water Education, Wageningen.

[18] Scheumann, W. and Freisem, C. (2002) The Role of Drainage for Sustainable Agriculture. Journal of Applied Irrigation Science, 37, 33-61.

[19] Ritzema, H.P., Satyanarayana, T.V., Raman, S. and Boonstra, J. (2008) Subsurface Drainage to Combat Water-Logging and Salinity in Irrigated Lands in India: Lessons Learned in Farmers' Fields. Agricultural Water Management, 95, 179-189. https://doi.org/10.1016/j.agwat.2007.09.012

[20] Nijland, H.J. (2000) Drainage along the River Nile. RIZA Nota, Lelystad, 323 p.

[21] Mohamed, G. (2018) Magnitude and Characteristics of Sand Dunes Encroachment towards El-Sheikh Gaber Channel, North Sinai, Egypt. 21 st International Water Technology Conference, Ismailia, 28-30 June 2018, 43-47.

[22] Channel Maintenance Research Institute, National Water Research Center, Ministry of Water Resources and Irrigation (MRWI) (2010) Assessing of the Irrigation and Drainage Network Maintenance at the North Sinai Project. Technical Report submitted to the Sector of Irrigation, Water Resources and Infrastructures in the North of Sinai. Channel Maintenance Research Institute, El-kanater El-khairia, MWRI, Egypt. (In Arabic)

[23] APHA, AWWA, and WEF (2012) Standards Methods for the Examination of Water and Wastewater. 22nd Edition, Washington DC.

[24] Egypt Decree, 92/2013 for the Protection of the Nile River and Its Waterways from Pollution. Decree of Minister of Water Resources and Irrigation No. 92 for Year 2013 for the Executive Regulation of Law 48/1982, 92/2013, FAO, FAOLEX. https://www.mwri.gov.eg/index.php/ministry/ministry-17/12-1985

[25] Drainage Research Institute (DRI), National Water Center, Ministry of Water Resources and Irrigation (MRWI) (2015) Study of Water Quality in Sheikh Gaber Canal, East South EL-Qantara Canal, Some Branch Canals, and Main Drains in the North Sinai Project (Final Report) for the Period from 2010 to 2014. Technical Report submitted to the Sector of Irrigation, Water Resources, and Infrastructures in the North of Sinai. DRI, El-kanater El-khairia, MWRI, Egypt. (In Arabic)

[26] Gad, A. (2016) Sand Dune Distribution and Related Impacts on Agricultural Resources of Sinai Peninsula, Egypt, Using Integrated Remote Sensing-GIS Techniques. Global Advanced Research Journal of Agricultural Science, 5, 42-50.

[27] Yasser, A., Mahmoud, A. and Shaymaa, O. (2015) Plant Diversity of the Damietta Branch, River Nile, Egypt: An Ecological Insight. Mesopotamia Environmental Journal, 1, 109-129.

[28] Amrapalli, G. and Joel, S. (2013) River Bank Protection. CIVE 717.

[29] Phocaides, A. (2000) Technical Handbook on Pressurized Irrigation Techniques. FAO, Rome, 372.

[30] Kumar, M., Kumari, K., Ramanathan, A.L. and Saxena, R.A. (2007) Comparative Evaluation of Groundwater Suitability for Irrigation and Drinking Purposes in Two Intensively Cultivated, Districts of Punjab, India. Environmental Geology, 53, 553-574. https://doi.org/10.1007/s00254-007-0672-3 